\section{National Preparedness Month - September 2018}

Each September, CDC, along with 3,000 global, national, regional, and local governments, as well as private and public health institutions, supports emergency preparedness efforts and encourages U.S. residents to take action before, during, and after an emergency. Every community in the United States needs to be ready to respond to an infectious disease outbreak, a chemical or radiologic release, or a natural disaster (1). Public health systems need the capacity to scale up and respond to emergencies (2).

This year marks the 100th anniversary of the 1918 influenza pandemic, which resulted in an estimated 50 to 100 million deaths (3). Planning and preparedness for all types of public health emergencies are vital to keeping communities safe.

This year, CDC is highlighting four areas: 1) personal preparedness, 2) pandemic planning, 3) policy and partnerships, and 4) public health response. Personal preparedness helps communities to be more resilient in the event of an emergency. Through pandemic planning, CDC works to protect the nation from seasonal and pandemic influenza, and through partnerships, CDC plays a pivotal role in state and local readiness. CDC's Emergency Operations Center and the Division of State and Local Readiness bring together experts and state-of-the-art technology to detect and respond to public health emergencies, such as the recent Zika virus outbreak featured in this issue of $M M W R(4)$. Additional resources are available at https://www.cdc.gov/phpr/index.htm.

\section{References}

1. CDC. In an emergency you can't respond effectively if you are not ready. Atlanta, GA: US Department of Health and Human Services, CDC; 2018. https://www.cdc.gov/phpr/whatwedo/emergency.htm

2. Redd SC, Frieden TR. CDC's evolving approach to emergency response. Health Secur 2017;15:41-52. https://doi.org/10.1089/ hs.2017.0006

3. Belser JA, Tumpey TM. The 1918 flu, 100 years later. Science 2018;359:255. https://doi.org/10.1126/science.aas9565

4. Murthy BP, Vagi S, Desamu-Thorpe R, Avchen R. Assessment of state, local, and territorial Zika planning and preparedness activities_-United States, June 2016-July 2017. MMWR Morb Mortal Wkly Rep 2018;67:969-73.

\section{Assessment of State, Local, and Territorial Zika Planning and Preparedness Activities - United States, June 2016-July 2017}

\author{
Bhavini Patel Murthy, $\mathrm{MD}^{1,2}$; Sara Vagi, $\mathrm{PhD}^{2}$; \\ Rodel Desamu-Thorpe, $\mathrm{MD}^{2}$; Rachel Avchen, $\mathrm{PhD}^{2}$
}

The emergency response to Zika virus disease required coordinated efforts and heightened collaboration among federal, state, local, and territorial public health jurisdictions. CDC activated its Emergency Operations Center on January 21, 2016, with seven task forces to support the national response. The State Coordination Task Force, which functions as a liaison between jurisdictions and federal operations during a response, coordinated the development of CDC Guidelines for Development of State and Local Risk-based Zika Action Plans, which included a Zika Preparedness Checklist (1). The checklist summarized recommendations covering topics from the seven task forces. In July 2016, CDC's Office of Public Health Preparedness and Response (OPHPR) awarded \$25 million in supplemental funding to 53 jurisdictions (41 states, eight

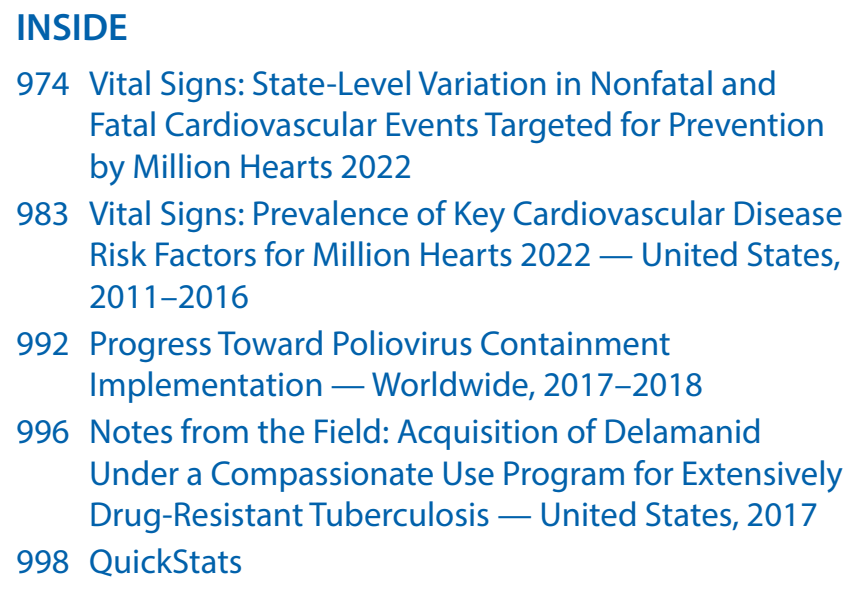
Fatal Cardiovascular Events Targeted for Prevention by Million Hearts 2022

983 Vital Signs: Prevalence of Key Cardiovascular Disease Risk Factors for Million Hearts 2022 — United States, 2011-2016

992 Progress Toward Poliovirus Containment Implementation - Worldwide, 2017-2018

996 Notes from the Field: Acquisition of Delamanid Under a Compassionate Use Program for Extensively Drug-Resistant Tuberculosis — United States, 2017

998 QuickStats

Continuing Education examination available at https://www.cdc.gov/mmwr/cme/conted_info.html\#weekly.

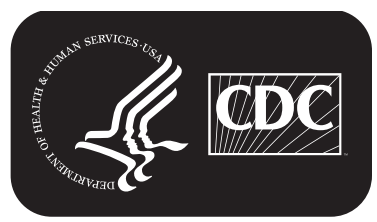

